\title{
Surgical Outcome of Peritoneal Dialysis Catheter Insertion in Pediatric Patients: An Experience in Iran
}

\author{
Fariba Jahangiri, ${ }^{1, *}$ Nakysa Hooman, ${ }^{2}$ and Nasibeh Khaleghnejad-Tabari ${ }^{3}$ \\ ${ }^{1}$ Department of Pediatric Surgery, Ali-Asghar Children Hospital, Iran University of Medical Sciences, Tehran, Iran \\ ${ }^{2}$ Department Pediatric Nephrology, Ali-Asghar Children Hospital, Iran University of Medical Sciences, Tehran, Iran. \\ ${ }^{3}$ Pediatric Surgery Research Center, Shahid Beheshti University of Medical Sciences, Tehran, Iran \\ Corresponding author: Fariba Jahangiri, Department of Pediatric Surgery, Ali-Asghar Children Hospital, Iran University of Medical Sciences, Tehran, Iran. Tel: +98-9121056367, \\ E-mail: jahanf89@gmail.com
}

Received 2016 November 18; Revised 2017 April 15; Accepted 2017 July 07.

\begin{abstract}
Background: Early and late surgical complications of peritoneal dialysis (PD) come along with important and sometimes devastating morbidity, interference of medical care, decreased performance of dialysis, eventually increase the rate of mortality. The aim of our study was to evaluate the changes in the rate of surgical complications and the outcome of PD catheter insertion in a tertiary center in Iran since starting PD program.

Methods: This was a retrospective cohort study conducted between 1993 and 2012. Inclusion criteria were all children aged 14 years or younger with chronic kidney disease who underwent peritoneal dialysis. Patients with acute peritoneal dialysis and those who were followed up for less than six months were excluded. eGRF was calculated using Schwartz formula. The surgical complications including catheter malfunction, leak, Dacron sheet extrusion, and hernia were considered. Catheter survival, rate of catheter changes, and rate of peritonitis were calculated in two time period. P value less than 0.05 was considered as statistically significant. Results: During a 19 year interval, 86 PD catheters were inserted in 50 patients, with a median (range) age of 22.5 (1-192) months. The most common underlying diseases were CAKUT (congenital anomaly of kidney and urinary tract, 32\%), cystic kidney disease (26\%), congenital nephrotic syndrome (16\%), and hemolytic uremic syndrome (14\%). Median eGFR at the time of operation was 7.8 (4 - 31.4 $\mathrm{mL} / \mathrm{min} / 1.73 \mathrm{~m}^{2}$ ). Catheters were inserted laparoscopically in $4.6 \%$. Among surgical complications, $39 \%$ of patients developed hernia in median of five months after surgery, in addition catheter malfunction, dislocation, adhesion, or cuff extrusion developed in $22 \%$ of cases. The most common reasons for removal were catheter related (outflow failure, adhesion, cuff extrusion) (21\%) and infection (peritonitis, tunnel infection) (17.4\%). Reoperation for catheter related complication was required in 21 (42\%) patients. However, the number and the cause of catheter exchange and the outcome of patients were not statistically significant in two time periods; The rate of outflow failure (77\% vs. 25\%), peritonitis rate (1 per 7.5 vs. 56.9 patient-months) and catheter reinsertion rate (1 per 30.8 vs. 63.7 patient-months) improved significantly from the time period before 2005 and afterward. The median (range) follow up of patients was 29 (6 - 126) months. Almost 20\% transplanted, $-26 \%$ were still on CAPD, $6 \%$ switched to hemodialysis, renal function recovered in $10 \%$, and $38 \%$ died.

Conclusions: This study shows that although improvement in our technique has been accomplished and complications related to technique of insertion are declining; catheter and patient outcomes still are far from standard.
\end{abstract}

Keywords: Peritoneal Dialysis, Continuous Ambulatory Care, Kidney Failure, Intraoperative Complications, Catheters, Child, Iran

\section{Background}

An alternative therapy for children with end stage renal disease (ESRD) waiting for kidney graft is peritoneal dialysis (PD). PD catheters, being easily implanted transcutaneously, are expected to function for a reasonable lifespan. However, catheter related complications including infection, leakage, catheter dysfunction, and displacement remain to be dealt with (1).

Complications of PD come along with important and sometimes devastating morbidity, interference of medical care, decreased performance of dialysis, and eventually increase the rate of mortality. Moreover, lead to haemodialy- sis, increase the rate of hospitalization, and succeeding operation. These adverse effects restrict the durable survival of PD catheters in a third to half of cases after two years (2).

The optimal target for PD centers is a catheter survival rate of $80 \%$ for the first year after catheter implantation (35).

The international society for peritoneal dialysis (ISPD) guideline recommends the acceptable rate of peritonitis to be less than 0.67 episodes per patient-year at risk (equal to one incidence in 18 patient-months) (6).

The prevalence of chronic renal failure in Iranian children is 118.8 per million $(7,8)$ and since 1993 when continuous ambulatory peritoneal dialysis (CAPD) was first intro-

Copyright (c) 2017, Iranian Journal of Pediatrics. This is an open-access article distributed under the terms of the Creative Commons Attribution-NonCommercial 4.0 International License (http://creativecommons.org/licenses/by-nc/4.0/) which permits copy and redistribute the material just in noncommercial usages, provided the original work is properly cited. 
duced in Iran, it has become the preferred renal replacement therapy (RRT) for neonates, infants, and young children (9). The aim of our study was to evaluate the trend of catheter survival of pediatric patients on PD and to estimate the rate of surgical complications due to catheter insertion.

\section{Methods}

Data of all children who underwent continuous peritoneal dialysis between 1993 and 2012 in Ali-Asghar Children's hospital are evaluated in this retrospective study. Year 2005 is taken as cut point of comparison because prior to that time PD catheter could be inserted by all surgeons in our unit but according to latest PD consensus this policy has changed and only one expert surgeon was appointed to insert catheters. Inclusion criteria were 1) age less than 14 years, 2) severe chronic kidney disease delineated by creatinine clearance below $15 \mathrm{~mL} / \mathrm{min} / 1.73 \mathrm{~m}^{2}$ and admitted electively or emergently for uremic symptoms, fluid overload, or severe electrolyte imbalance, 3) patients under followed-up for at least six months. Patients referred from other centers for catheter insertion and those with follow-up period of less than six months or those who died in the first month of catheter insertion were excluded from outcome analysis. Patients whose renal function recovered after at least six months were included in the study.

The only catheters available for CAPD in children were soft curled swan neck Tenckhoff catheters with two Dacron cuffs for children and straight one for infants and neonates without stylet. Here is a brief description of open surgical technique: The suitable site of entrance was marked on the skin by placing the catheter on the midline surface of the abdomen. After that, one centimeter to the midline, a small incision was made. Then, partial omentectomy performed. Subsequently, the tip of catheter inserted and pushed to the pelvic space behind the bladder. After pursing around the catheter, the tunnel was created subcutaneously and the distal cuff was placed $2 \mathrm{~cm}$ of the exit site. Only adolescent patients were candidates for placement of catheters by laparoscopy that was recently started in our department. The patients were routinely followed every month for the first three months after surgery and then every three months by pediatric nephrologist.

Data including demographic characteristic of patients, surgical complications of CAPD and catheter outcome were collected from hospital records. For analysis, we assessed the incidence and aspect of complications including infection-related (peritonitis, tunnel infection) and catheter-related (leak, Dacron cuff extrusion, adhesion, dislocation, hernia). Peritonitis was illustrated based on the ISPD endorsement as the existence of at least two of the consecutive criteria: clinical presentation of peritoneal inflammation; a cloudy effluent with cells more than 100 cells $/ \mathrm{mm}^{3}$, and positive culture of peritoneal fluid. Exit site infection was delineated as the existence of a purulent discharge from the sinus tract or pronounced swelling around catheter, reddening and/or tenderness. Leakage defined by pericatheter fluid leakage, hydrocele, genital edema, and pleural effusion). The patient information remained anonymous. According to training hospital policy, all care givers or parents signed a consent form for catheter insertion and the utilization of the data at the time of admission. It was a retrospective study; therefore no ethical approval was required.

\section{Results}

During a 19 year period 69 patients, underwent peritoneal dialysis catheter insertion. Of them 19 patients were excluded (Figure 1). At dialysis initiation the number of children was: aged 12 months or younger 18 (36\%), between 12 and 24 months 12 (24\%), and older than 2 years 20 (40\%).

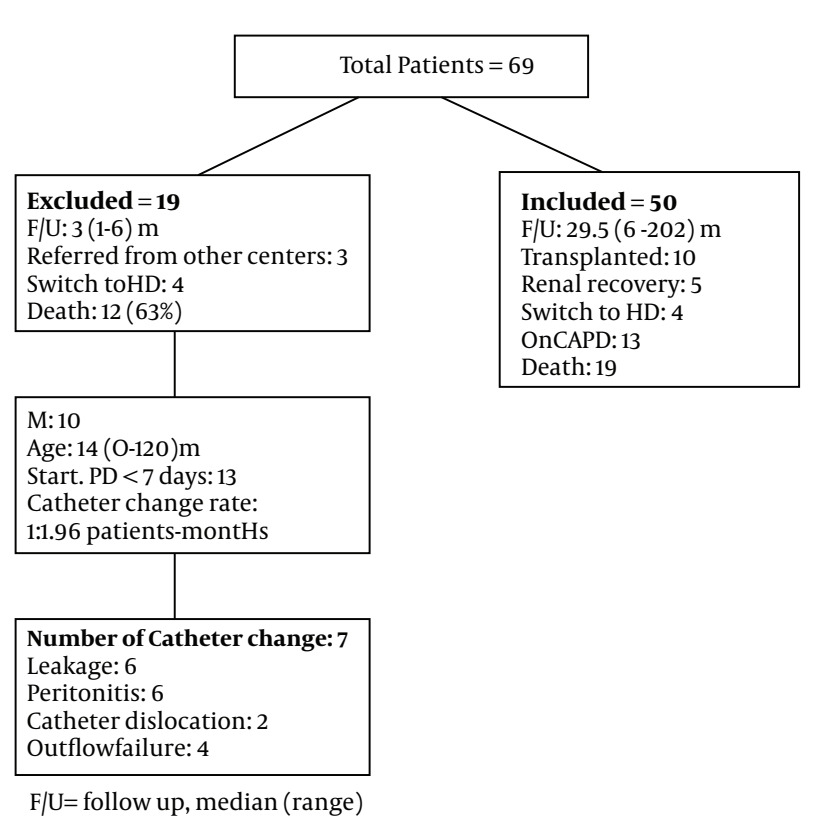

Figure 1. Flowchart of Patients Enrolled in Study (1993 - 2012)

The most common underlying diseases were CAKUT and cystic kidney disease. Other underlying disorders of ESRD are summarized in Table 1.

Totally 86 catheters were inserted, Table 2 shows the number of catheter changes. The changes took place because of surgical complications and the outcome of patients. Figure 2 shows the cumulative catheter-related survival of PD in two time periods. The $75 \%$ catheter survival 
Table 1. Demographic Data and Laboratory Status of Patients at the Time of Catheter Insertion

\begin{tabular}{|c|c|c|c|}
\hline Variables & $<2005, \mathrm{~N}=14$ & $>2005, N=36$ & P Value \\
\hline Age, median (range), mo & $11(3-72)$ & $24(1-192)$ & 0.083 \\
\hline Male, No. (\%) & $7(50)$ & $23(62)$ & 0.52 \\
\hline Weight, Kg, mean (SD) & $8(3.5)$ & $12(8)$ & NS \\
\hline Height, cm, mean (SD) & $89.5(11.2)$ & $83(20)$ & 0.027 \\
\hline $\begin{array}{l}\text { Underlying disease, No. } \\
(\%)\end{array}$ & & & 0.7 \\
\hline CAKUT & $5(36)$ & $11(31)$ & \\
\hline CNS & $3(21)$ & $5(14)$ & \\
\hline Cystic disease & $3(21)$ & $10(28)$ & \\
\hline Cystinosis & 0 & $1(3)$ & \\
\hline Hyperoxaluria & 0 & $3(8)$ & \\
\hline HUS & $3(21)$ & $4(11)$ & \\
\hline Tubulopathy & 0 & $2(5)$ & \\
\hline Hypertension, No. (\%) & & & 0.057 \\
\hline $\begin{array}{l}\text { SBP or DBP }>95 \% \text { for } \\
\text { age, height, sex }\end{array}$ & 8 of $12(67)$ & 11 of $32(33)$ & \\
\hline $\begin{array}{l}\text { eGFR, } \mathrm{mL} / \mathrm{min} / 1.73 \mathrm{~m}^{2} \text {, } \\
\operatorname{mean}(\mathrm{SD})\end{array}$ & $9(2.2)$ & $9.5(5.6)$ & NS \\
\hline
\end{tabular}

Abbreviations: CAKUT, Congenital Abnormality of Kidney and Urinary Tract; CNS, Congenital Nephrotic Syndrome; DBP, Diastolic Blood Pressure; HUS Hemolytic Uremic Syndrome; SBP, Systolic Blood Pressure.

improved from nine months in the first period to twelve months after that (Pvalue $<0.05)$. The same improvement was seen in the first catheter survival; however it was not statistically significant (Figure 3). While catheter related reason was the most common cause of catheter removal or changes before 2005, afterward renal recovery was the dominant reason. Unfortunately, infection comprised still more than one fifth of catheter removals. Hernia developed in more than one third of patients. The median time for hernia occurrence was five (1 - 13) months after initiation of dialysis.

Catheter reinsertion rate improved from 1 per 30.76 (before 2005) to 1 per 63.72 patient-months (after 2005). The median (range) follow up of patients was 29.5 (6 - 126) months.

Seven cases of outflow failure were due to fibrin clot in 2 , rotation of catheter in 2, and adhesions in 3 cases. Figure 2 shows the $25 \%, 50 \%$ and $75 \%$ survival of the first PD catheter survival in two time period. There was improvement of survival after in the years after 2005 but the difference was not significant.

The rate of peritonitis was one per 7.5 patients-month (before 2005) and declined to one per 56.89 patients-
Table 2. The Rate of Catheter Insertion and Surgical Complications

\begin{tabular}{|c|c|c|c|}
\hline Variables & $<2005, N=14$ & $>2005, N=36$ & P Value \\
\hline Number of catheters re-inserted & & & NS \\
\hline 0 & 7 & 21 & \\
\hline 1 & 4 & 9 & \\
\hline 2 & 2 & 5 & \\
\hline 3 & 1 & 0 & \\
\hline 6 & 0 & 1 & \\
\hline \multicolumn{4}{|l|}{$\begin{array}{l}\text { Technique of Catheter insertion, } \\
\text { No. (\%) }\end{array}$} \\
\hline Laparoscope & 0 & $4(4.6)$ & \\
\hline $1^{\text {st }}$ catheter survival, months & & & 0.12 \\
\hline $25 \%$ & 24 & 36 & \\
\hline $50 \%$ & 10 & 24 & \\
\hline $75 \%$ & 9 & 12 & \\
\hline Reason of catheter change, No. (\%) & & & 0.35 \\
\hline Catheter related & $6(43)$ & $7(19)$ & \\
\hline Infectious related & $3(21.4)$ & $9(24)$ & \\
\hline $\begin{array}{l}\text { Renal function } \\
\text { recovery/renal transplant }\end{array}$ & $3(21.4)$ & $14(38)$ & \\
\hline Outcome, No. (\%) & & & 0.52 \\
\hline Transplanted & $1(7)$ & $9(24)$ & \\
\hline Renal recovery & $2(14)$ & $3(8)$ & \\
\hline On CAPD & $3(21)$ & $10(27)$ & \\
\hline Switch to HD & $2(14)$ & $2(5)$ & \\
\hline Death & $6(43)$ & $13(35)$ & \\
\hline Surgical complications & & & NS \\
\hline Hernia, №. (\%) & $6(42.8)$ & $13(36)$ & \\
\hline Incisional & 1 & 4 & \\
\hline Inguinal & 3 & 9 & \\
\hline Umblical & 2 & 0 & \\
\hline Outflow failure, No. (\%) & $10(77)$ & $12(25)$ & 0.001, RR: $1.69(1.14-2.5)$ \\
\hline Leak, No. (\%) & $8(57)$ & $15(40.5)$ & 0.28 \\
\hline Pleural effusion & 1 & 1 & \\
\hline hydrocele & 0 & 4 & \\
\hline $\begin{array}{l}\text { Time to leak (months, median } \\
\text { (range) }\end{array}$ & $5.5(1-10)$ & $6(1-27)$ & NS \\
\hline Persistent peritonitis & $3(21)$ & $17(47)$ & 0.11 \\
\hline $\begin{array}{l}\text { Start PD immediately (< 7days), No. } \\
\text { (\%) }\end{array}$ & $9(64)$ & $10(27)$ & $0.23, \mathrm{RR}: 2.37(1.23-4.59)$ \\
\hline
\end{tabular}

month. Causative organisms for peritonitis in our patients are summarized in Table 3.

\section{Discussion}

This study revealed that first catheter survival improved dramatically compared to the previous study in Iran (9) but it is still much lower than that in other developing countries $(10,11)$.

In our study the first year catheter survival was about $75 \%$ and it was comparable to the registry of Italy. The catheter reinsertion rate decreased from 1 per 31 to one per 64 patient- month. A large multicenter registry in Italy 


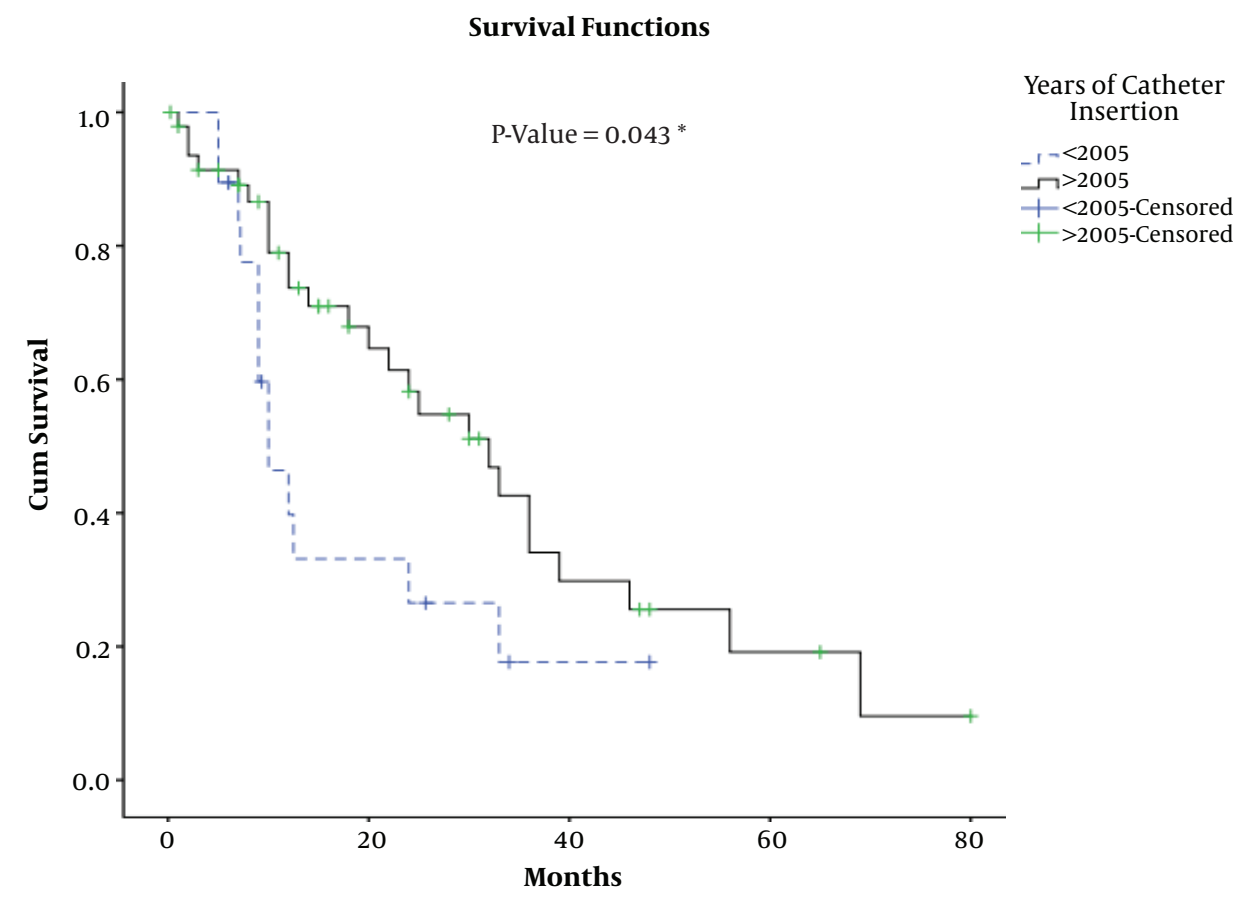

\begin{tabular}{|l|c|c|c|c|}
\hline \multicolumn{4}{|c|}{${ }^{*}$ Log Rank (Mantel-Cox) } \\
\cline { 3 - 5 } Years of & \multicolumn{3}{|c|}{ Mean } \\
Catheter & & & \multicolumn{2}{|c|}{$95 \%$ Confidence Interval } \\
\cline { 4 - 5 } Inserion & \multirow{2}{*}{ Months } & Std. & Lower & \\
& & Error & Bound & Upper Bound \\
\hline$<2005$ & 18.92 & 3.92 & 11.22 & 26.62 \\
$>2005$ & 34.25 & 4.36 & 25.69 & 42.81 \\
Overall & 30.70 & 3.67 & 23.49 & 37.90 \\
\hline
\end{tabular}

Percentiles

\begin{tabular}{|l|c|c|c|c|c|c|}
\hline \multirow{2}{*}{$\begin{array}{l}\text { Years of Catheter } \\
\text { Insertion }\end{array}$} & \multicolumn{2}{|c|}{$25 \%$} & \multicolumn{2}{c|}{$50 \%$} & \multicolumn{2}{c|}{$75 \%$} \\
\cline { 2 - 7 } & Months & $\begin{array}{c}\text { Std. } \\
\text { Error }\end{array}$ & Months & $\begin{array}{c}\text { Std. } \\
\text { Error }\end{array}$ & Months & $\begin{array}{c}\text { Std. } \\
\text { Error }\end{array}$ \\
\hline$<2005$ & 33 & 13.76 & 10 & 1.86 & 9 & 0.99 \\
$>2005$ & 56 & 11.36 & 32 & 5.13 & 12 & 3.67 \\
Overall & 46 & 8.6 & 24 & 5.99 & 10 & 0.83 \\
\hline
\end{tabular}

Figure 2. Comparison of Survival Functions of All Tenckhoff Catheters Inserted Between 1993 - 2012

reported the outcome of 503 surgically inserted catheter in children. The first year catheter survival was $78 \%$ and the rate of catheter reinsertion was one per 17.9 patientmonths. In their registry leakage and dislocation were followed by infection as the most frequent complication after surgery (12).

Al Salum et al reported 63 catheter insertions in 48 children with a catheter insertion rate of one per 9.65 patientmonths (13). Peritonitis was the main complication among PD patients in Saudi Arabia. Median catheter survival of 


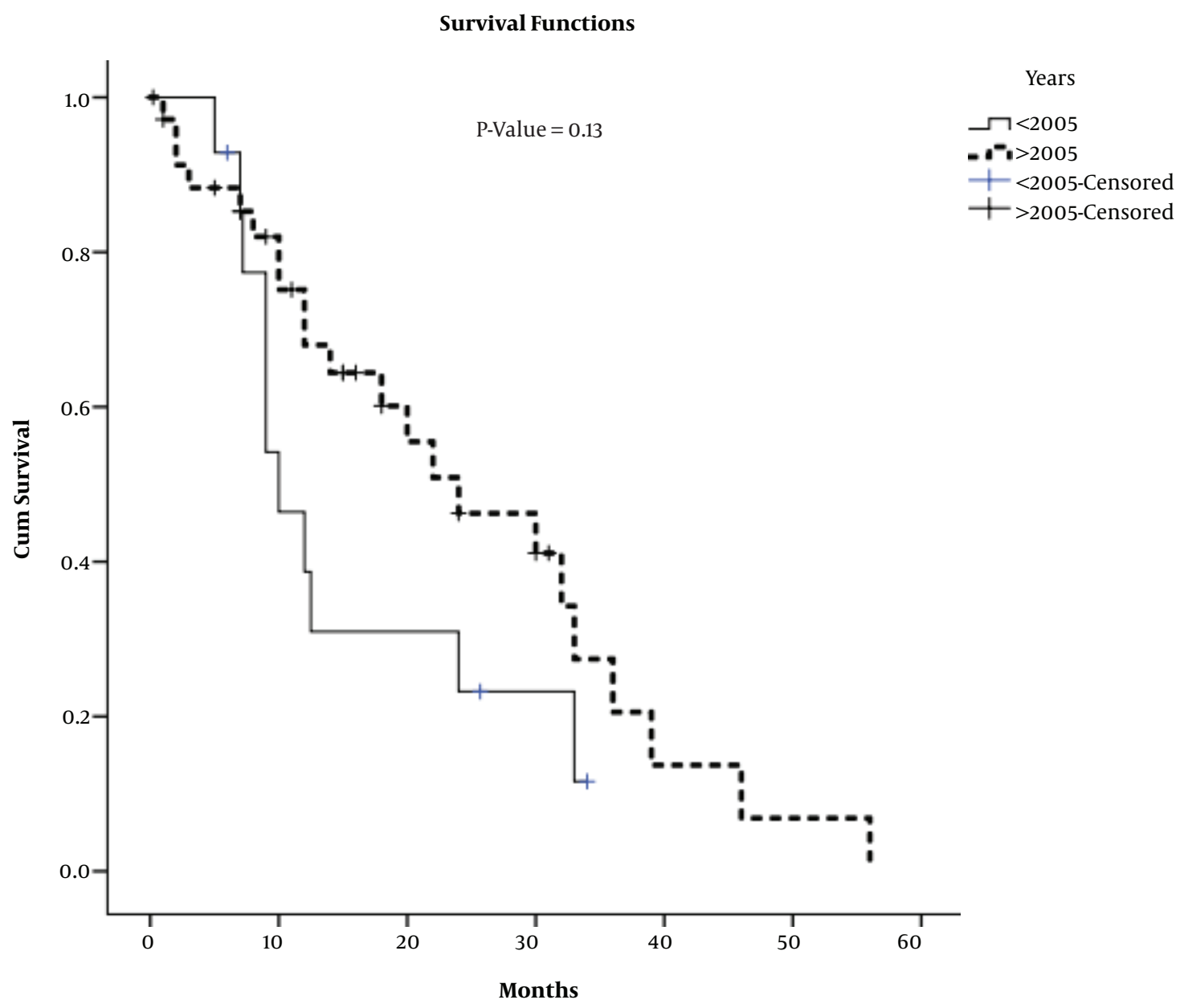

Comparison of Survival of $1^{\text {st }}$ PD Catheter in Two Periods (Log-Rank, Mantel-Cox)

\begin{tabular}{|l|c|c|c|c|c|c|}
\hline \multirow{2}{*}{ Years } & \multicolumn{2}{|c|}{$25 \%$} & \multicolumn{2}{c|}{$50 \%$} & \multicolumn{2}{c|}{$75 \%$} \\
\cline { 2 - 7 } & Estimated & Std. Error & Estimated & Std. Error & Estimated & Std. Error \\
\hline$<2005$, Months & 24 & 12.4 & 10 & 1.7 & 9 & 0.9 \\
$>2005$, Months & 36 & 3.3 & 24 & 6.9 & 12 & 2.4 \\
Overall, Months & 33 & 2.2 & 20 & 5.2 & 9 & 0.9 \\
\hline
\end{tabular}

Figure 3. Survival of First Peritoneal Dialysis Catheter

27 Indian children on CAPD was 9.11 months, of whom, ten children younger than five years old had catheter obstruction due to omentum block (14). In TUPEPD registry the majority of catheters implanted with open surgical technique and the overall first catheter survival was 95\%. The outcome was much better than in our center $(15,16)$. A six-year report of dialysis in children from Saudi Arabia, states that 19 out of 48 patients on CAPD had PD failure and the cause was obstruction in half of the cases (17).

In the first period of study about two thirds of catheters had outflow failure. The outflow failure rate declined to $20 \%$ in the second period of study. However, we 
Table 3. Causative Microorganisms of Peritonitis

\begin{tabular}{|c|c|c|c|}
\hline Etiology & $\begin{array}{l}<2005, \mathrm{~N}=14 \\
\text { (36 Episodes) }\end{array}$ & $\begin{array}{l}>2005, N=36 \\
(40 \text { Episodes) }\end{array}$ & PValue \\
\hline $\begin{array}{l}\text { Gram Positive, } \\
\text { No. (\%) }\end{array}$ & $17(47.2)$ & $11(27.5)$ & 0.07 \\
\hline SAU & 4 & 6 & \\
\hline $\begin{array}{l}\text { Enter- } \\
\text { obacter }\end{array}$ & 0 & 2 & \\
\hline MRSA & 10 & 0 & \\
\hline CONS & 3 & 3 & \\
\hline $\begin{array}{l}\text { Gram } \\
\text { Negative, No. } \\
(\%)\end{array}$ & $3(8.3)$ & $15(37.5)$ & $\begin{array}{c}0.003,95 \% \mathrm{CI} \\
(8.7-47.1)\end{array}$ \\
\hline E. coli & 1 & 4 & \\
\hline $\begin{array}{l}\text { Pseu- } \\
\text { domonas }\end{array}$ & 1 & 6 & \\
\hline $\begin{array}{l}\text { Kleb- } \\
\text { siella }\end{array}$ & 0 & 3 & \\
\hline $\begin{array}{l}\text { Acineto- } \\
\text { bacter }\end{array}$ & 1 & 2 & \\
\hline Fungal, No. (\%) & $1(2.7)$ & $4(10)$ & 0.2 \\
\hline $\begin{array}{l}\text { Candida } \\
\text { albicans }\end{array}$ & 1 & 1 & \\
\hline $\begin{array}{l}\text { Mu- } \\
\text { comyco- } \\
\text { sis }\end{array}$ & 0 & 1 & \\
\hline $\begin{array}{l}\text { Culture } \\
\text { Negative, No. } \\
(\%)\end{array}$ & $15(41.6)$ & $10(25)$ & 0.12 \\
\hline $\begin{array}{l}\text { Peritonitis } \\
\text { rate }\end{array}$ & $\begin{array}{c}1 \text { per } 7.5 \\
\text { patients-month }\end{array}$ & $\begin{array}{c}1 \text { per } 56.89 \\
\text { patients-month }\end{array}$ & \\
\hline
\end{tabular}

Abbreviations: CONS, Coagulase Negative Streptococcus; MRSA, Methicillin Resistant Staphylococcus Aureus; SAU, Staphylococcus Aureus.

routinely do partial omentectomy, the main cause of outflow failure was adhesion and then catheter dislocation in both periods. The five year technique survival was $50 \%$ in our study that was lower than the national reports. Although the catheter survival improved in the second period of study but the rate was still below the standard level (18). A multicenter report of presternal catheter for PD in Poland had a median catheter survival of 72 months (19). Complications related to technique were relatively low in our study compared to other studies which could be attributed to our increased experience, since more and more cases of pediatric ESRD patients receive PD in our country.

One of the best advantages was significant reduction in peritonitis rate when we compared the in two periods of study. It had declined from one per 7.5 patient-months to one per 56.9 patients- month. This improvement is related to good nursing care, improvement in connection system, re-evaluation of techniques every six months by the dialy- sis nurse, screening for staphylococcus carrier and appropriate treatment before catheter insertion, we did not have any case of MRSA peritonitis after 2005 but unfortunately the rate of gram negative peritonitis doubled in the second period of study. Regarding to peritonitis rate of TUPEPD that was one per 15.5 patient-months to one per 63 patientmonths, our result was comparable. (16).

One of the major post catheter complications was the occurrence of hernia and leakage. That the frequency of them had not changed much. We did not find any relation between leakage and malnutrition ((P value: 0.2; OR: 1.68(95\% CI: $0.58-4.8)$ ) or the early onset of dialysis ((P value $=0.054$, OR: 2.84 (95\% CI: 0.96 - 8.37)).

The main limitation of this study was its being a retrospective study and the high rate of drop outs or missing cases because some patients had been referred from other centers for catheter insertion. This study showed that despite the fact that our technique and experience is improving the management of catheter and infections related to it are still weak and need to be addressed in order to reach the standard CPD care.

\subsection{Conclusion}

This study showed that although improvement in our technique has been accomplished and complications related to technique of insertion are declining; management and care of the catheter in order to reduce peritonitis is still insufficient and more should be done to educate nurses and parents and care givers in this regard.

\section{Acknowledgments}

This study has been approved by research board of Iran University of Medical Sciences register number 130, dated 19 April 2012.

\section{References}

1. Rahim KA, Seidel K, McDonald RA. Risk factors for catheter-related complications in pediatric peritoneal dialysis. Pediatr Nephrol. 2004;19(9):1021-8. doi: 10.1007/s00467-004-1520-2. [PubMed: 15206031].

2. Sanderson MC, Swartzendruber DJ, Fenoglio ME, Moore JT, Haun WE. Surgical complications of continuous ambulatory peritoneal dialysis. Am J Surg. 1990;160(6):561-5. doi: 10.1016/S0002-9610(05)80746-9. [PubMed: 2252113] discussion 565-6.

3. Tiong HY, Poh J, Sunderaraj K, Wu YJ, Consigliere DT. Surgical complications of Tenckhoff catheters used in continuous ambulatory peritoneal dialysis. Singapore Med J. 2006;47(8):707-11. [PubMed: 16865213].

4. Keshvari A, Fazeli MS, Meysamie A, Seifi S, Taromloo MK. The effects of previous abdominal operations and intraperitoneal adhesions on the outcome of peritoneal dialysis catheters. Perit Dial Int. 2010;30(1):41-5. doi: 10.3747/pdi.2008.00121. [PubMed: 20056978]. 
5. Flanigan M, Gokal R. Peritoneal catheters and exit-site practices toward optimum peritoneal access: a review of current developments. Perit Dial Int. 2005;25(2):132-9. [PubMed: 15796138].

6. Piraino B, Bailie GR, Bernardini J, Boeschoten E, Gupta A, Holmes C, et al. Peritoneal dialysis-related infections recommendations: 2005 update. Perit Dial Int. 2005;25(2):107-31. [PubMed: 15796137].

7. Gheissari A, Kelishadi R, Roomizadeh P, Abedini A, HaghjooyJavanmard S, Abtahi SH, et al. Chronic Kidney Disease Stages 3-5 in Iranian Children: Need for a School-based Screening Strategy: The CASPIAN-III Study. Int J Prev Med. 2013;4(1):95-101. [PubMed: 23413177].

8. Madani K, Otoukesh $\mathrm{H}$, Rastegar A, Van Why S. Chronic renal failure in Iranian children. Pediatr Nephrol. 2001;16(2):140-4. doi: 10.1007/s004670000522. [PubMed: 11261681].

9. Hooman N, Esfahani ST, Mohkam M, Derakhshan A, Gheissari A, Vazirian $S$, et al. The outcome of Iranian children on continuous ambulatory peritoneal dialysis: the first report of Iranian National Registry. Arch Iran Med. 2009;12(1):24-8. [PubMed: 19111025].

10. Aksu N, Yavascan O, Anil M, Kara OD, Erdogan H, Bal A. A tenyear single-centre experience in children on chronic peritoneal dialysis-significance of percutaneous placement of peritoneal dialysis catheters. Nephrol Dial Transplant. 2007;22(7):2045-51. doi: 10.1093/ndt/gfm150. [PubMed: 17438008].

11. Kim PK, Kim JH. Pediatric peritoneal dialysis in Korea: practical solutions to the problems of peritoneal dialysis for children. Perit Dial Int. 1999;19 Suppl 2:S489-92. [PubMed: 10406570].

12. Rinaldi S, Sera F, Verrina E, Edefonti A, Gianoglio B, Perfumo F, et al. Chronic peritoneal dialysis catheters in children: a fifteen-year experience of the Italian Registry of Pediatric Chronic Peritoneal Dialysis.
Perit Dial Int. 2004;24(5):481-6. [PubMed: 15490990].

13. Al Salloum AA, Al Mugeiren MM, Al Rasheed S, Al Mazrou A, Al Zamil F. CAPD in saudi arabian children: ten years experience from a single center. Saudi J Kidney Dis Transpl. 1997;8(3):298-301. [PubMed: 18417810].

14. Senguttuvan P, Aravind S, Kumar R, Vengatesan A, Padrnaraj R, Ramamani D, et al. Outcome of CKD Children on CAPD. Indian J Perit Dial. 2010;19(2):18-21.

15. Bakkaloglu SA, Ekim M, Sever L, Noyan A, Aksu N, Akman S, et al. Chronic peritoneal dialysis in Turkish children: a multicenter study. Pediatr Nephrol. 2005;20(5):644-51. doi: 10.1007/s00467-004-1773-9. [PubMed: 15717162].

16. Ekim M, Bakkaloglu SA, Aksu N, Akman S, Noyan A, Sever L. Challenges in pediatric peritoneal dialysis in Turkey. Int Urol Nephrol. 2008;40(4):1027-33. doi: 10.1007/s11255-008-9451-7. [PubMed: 18770008].

17. Mahmoud AM, Hassab MH, El-Sibai MA, Mattoo TK. Six years' experience with continuous ambulatory peritoneal dialysis and chronic hemodialysis in Saudi children. Ann Saudi Med. 1993;13(6):516-9. doi: 10.5144/0256-4947.1993.516. [PubMed: 17589088].

18. Abraham G, Varughese $S$, Mathew M, Vijayan M. A review of acute and chronic peritoneal dialysis in developing countries. Clin Kidney J. 2015;8(3):310-7. doi:10.1093/ckj/sfv029. [PubMed: 26034593].

19. Warchol S, Roszkowska-Blaim M, Latoszynska J, Jarmolinski T, Zachwieja J. Experience using presternal catheter for peritoneal dialysis in Poland: a multicenter pediatric survey. Perit Dial Int. 2003;23(3):242-8. [PubMed: 12938824]. 